\title{
Design and analysis of base isolated structures
}

\author{
M. Amroyni Farissi \& R. Bambang Budiono \\ Institute Technology of Bandung, Indonesia
}

\begin{abstract}
Development in the design of earthquake resistant buildings has been growing since about 100 years ago. In the design of earthquake resistant buildings, the main aspects to consider are life safety and damage reduction on architectural element caused by the earthquake. However, with the development of age, modern buildings contain sensitive and expensive equipment that become vital for business, commercial, education and healthcare.

Hence, the equipment inside the building needs to be protected when the earthquake occurs. The basic principle of a base isolation system is to provide flexibility in the building and at the same time provide damping to prevent amplification caused by the earthquake. By placing structure on the base isolation system, it will prevent horizontal movement of the ground transferred to the structure and produce a significant reduction in the acceleration of the earthquake.

This paper explains about the design and analysis of a base isolated structure. The base isolation system used is Lead Rubber Bearings, High Damping Rubber Bearings, and a combination of those two bearings on a 20 -story building. The main focus of this paper is the comparison of the response between a fixed base structure and the base isolated structure and the comparison of the response generated by each type of base isolation system. The compared responses are the natural vibration period, the base shear, and the base isolation hysteretic curve. The design procedure used is based on SNI 1726-2012. The conclusion of this paper is the effectiveness of a base isolated structure is based on the generated response.

Keywords: base isolation, high damping rubber bearing, lead rubber bearing, non linear time history analysis.
\end{abstract}




\section{Introduction}

Modern buildings contain sensitive and expensive equipment that become vital for business, commercial, education and healthcare. This causes the contents and functions of the equipment inside the building to become more expensive than the structure of the building itself. Especially public facilities, such as: hospitals, emergency centers and communications, police stations, and fire stations, are obligated to provide service operationally as an indispensable condition as at the time of the earthquake [6].

Conventional building with rigid structures can cause high floor acceleration. While for conventional building with a flexible structures can cause large interstory drift. Both of these cause difficulty in designing earthquake-resistant buildings which are able to maintain the condition of building components and those inside the building [5].

On the development of earthquake-resistant buildings, a concept born to separate or at least reduce the acceleration of the earthquake which is channeled into the building. By placing structures on the base isolation system, will prevent horizontal earthquake acceleration which is transferred to structure. This produces a significant reduction in the reduction of seismic acceleration on each floor (floor acceleration) and interstory drift [4].

The basic principle of base isolation system is to provide flexibility in the base of the building and at the same time provide damping to prevent amplification caused by the earthquake. This will significantly help in reducing structural damage and non-structural damage, providing vital safety equipment in the building, and reducing the seismic acceleration transferred to the building [5].

\section{Theory}

\subsection{Single degree of freedom with base isolation}

One story building with base isolation system can be seen in the Figure 1 [3]. In the figure can be seen that the structure has similarities with the SDF system. Subscript $f$ states structure with fixed base (fixed) and subscript b states structure with base isolation system. The following are characteristics of the fixed base structure [3].

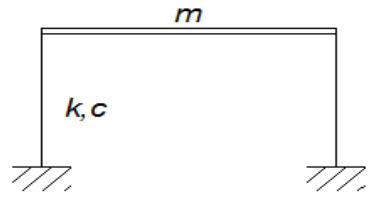

(a)

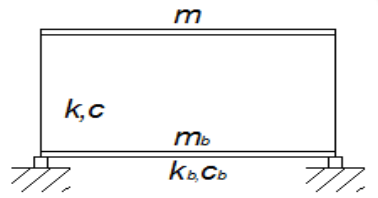

(b)

Figure 1: $\quad$ Single degree of freedom without base isolation (a) and with base isolation (b). 


$$
\omega_{f}=\sqrt{\frac{k}{m}} ; T_{f}=\frac{2 \pi}{\omega_{f}} ; \xi_{f}=\frac{c}{2 m \omega_{f}}
$$

where $\omega_{\mathrm{f}}$ is fixed base structure's frequency, $\mathrm{T}_{\mathrm{f}}$ is fixed base structure's natural period, and $\xi_{\mathrm{f}}$ is fixed base structure's damping ratio.

In figure 3, can also be seen structure with base isolation system. The following are characteristics of base isolated structure.

$$
\omega_{b}=\sqrt{\frac{k_{b}}{\left(m+m_{b}\right)}} ; T_{b}=\frac{2 \pi}{\omega_{b}} ; \xi_{b}=\frac{c}{2\left(m+m_{b}\right) \omega_{b}}
$$

where $\omega_{b}$ is base isolated structure's frequency, $T_{b}$ is base isolated structure's natural period, and $\xi_{\mathrm{b}}$ is base isolated structure's damping ratio.

\subsection{Basic concept of base isolation}

The term base isolation uses the word isolation in its meaning of the state of being separated and part that supports from beneath or serves as a foundation for an abject or structure (Concise Oxford Dictionary).

Figure 2 [5] shows that the reduction of seismic acceleration can be done by extending the fundamental period of structures (flexibility). Significant reduction can occur when the vibration period of the structure is also significantly increased. Furthermore, with the addition of flexibility in the structure to extend the period of the structure will result in increasing the relative displacement. A new breakthrough has been given to the concept of base isolation system with the success of the development of mechanical energy dissipaters and elastomers with high damping characteristics. Mechanical energy dissipaters, when combined with a flexible isolation device, can control the response structure by limiting the displacement and force. Therefore they will significantly improve the seismic performance [5].

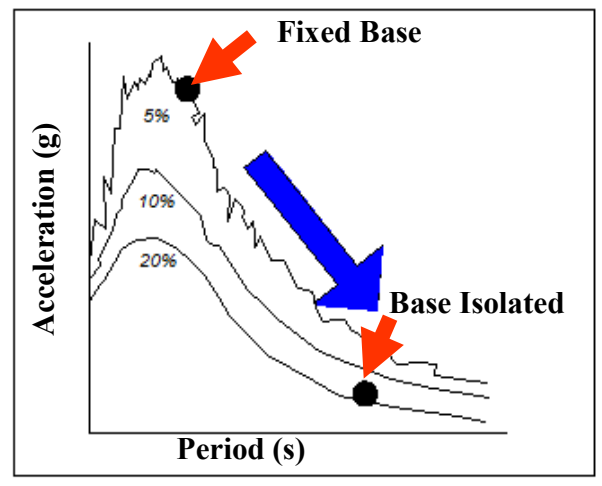

Figure 2: $\quad$ Period shift effect on acceleration spectra. 
The advantage of a base isolation system is the ability to significantly reduce damage of structural and non-structural elements to improve the security of buildings, building components, and architecture to reduce seismic design acceleration [6]. This potential advantage can be used for structures with high stiffness, such as low and medium-rise building, nuclear power plants, bridges, etc.

\section{Methodology}

\subsection{Design procedure}

Mentioned in the introductory section, this paper uses the example 20-story building. Therefore, the procedure of designing a 20-story building with a fixed base criteria and base isolation criteria becomes necessary. Several steps in the design procedure are:

1. Preliminary design

The preliminary design stage is to estimate the size of structural elements such as beam, column, shearwall, and slab [2].

2. Modelling

The modelling stage is to model the fixed structure. The modelling stage is divided into two models; the design model and the analysis model. The design model is used for preliminary analysis; it uses ETABS v9.7.4 software. The analysis model is used for nonlinear time history analysis by using SAP2000.

3. Earthquake design criteria based on SNI 1726-2012

Indonesia has a national code used for earthquake resistant building. The name is SNI 1726-2012 [1]. After modelling and inputing the gravitational load, the next step is calculating the base shear and checking the configuration of structure based on code.

4. Preliminary analysis

Preliminary analysis is for checking the stability, story drift, and torsional configuration of fixed base structure based on SNI 1726-2012 [1].

5. Base isolation preliminary design

The base isolation preliminary design is to estimate the stiffness and damping value of the high damping rubber and lead rubber bearing. For further information about preliminary design base isolation see reference [4-6].

6. Base isolation choice based on suppliers' data

After estimating the stiffness and damping value of the isolator, it has to be checked to the suppliers. For a high damping rubber bearing the supplier is Bridgestone and for lead rubber bearing the supplier is Dynamic Isolation System.

\subsection{Analysis procedure}

Non linear time history analysis (NLTHA) is used to finalize the design. Finalization of the design is done by checking the plasticity of the structure. 
Structures using base isolation system are not allowed having plasticity of structural elements.

\section{Design and modelling}

The fixed base base structure has been designed and fulfilled the criteria on preliminary analysis. This paper will not explicitly discuss about designing the upper structure and will mainly discuss about the design of base isolation.

\subsection{Base isolation criteria based on SNI 17262012}

In designing base isolation, there are several stages that Indonesia National Code (SNI 1726-2012) had determined. Here are the stages that have to follow based on SNI 1726-2012 [1].

1. Determine the target period

Generally, the target value of the period can be taken as 3 times the value of the natural vibration period of the structure. Structure that have been designed has natural vibration period 2.094 seconds. Retrieval target value 3 times the period of the structural system causing difficulties in finding base isolation system, therefore, the value of the target period $T_{D}=4.4 \mathrm{sec}$ and $\mathrm{T}_{M}$ $=4.6 \mathrm{sec}$ for high damping rubber bearings and $\mathrm{T}_{\mathrm{D}}=5.5$ seconds and $\mathrm{T}_{\mathrm{M}}=$ 5.8 seconds to lead rubber bearings. For further information for asumming this value see reference [4] and reference [5]

2. Estimate the stiffness value

For estimating the stiffness value, the heaviest weight of base points is needed. From the design of fixed base structure, the heaviest base point weighs $11269 \mathrm{kN}$. The following is the procedure of early stiffness estimation of high damping rubber bearing

$$
\begin{aligned}
& \mathrm{K}_{\mathrm{D}(\min )}=\left(\frac{2 \pi}{\mathrm{T}_{\mathrm{D}}}\right)^{2} \frac{\mathrm{W}}{\mathrm{g}}=\left(\frac{2 \pi}{4,4}\right)^{2} \frac{11269}{9,81}=2342,45 \mathrm{kN} / \mathrm{m} \\
& \mathrm{K}_{\mathrm{M}(\min )}=\left(\frac{2 \pi}{\mathrm{T}_{\mathrm{M}}}\right)^{2} \frac{\mathrm{W}}{\mathrm{g}}=\left(\frac{2 \pi}{4,6}\right)^{2} \frac{11269}{9,81}=2143,19 \mathrm{kN} / \mathrm{m}
\end{aligned}
$$

stiffness values are allowed to assume an error of $10 \%$, so the stiffness value becomes

$$
\begin{aligned}
& \mathrm{K}_{\mathrm{D}(\max )}=1,10.2239,50=2576,69 \mathrm{kN} / \mathrm{m} \\
& \mathrm{K}_{\mathrm{M}(\max )}=1,10.2413,19=2357,51 \mathrm{kN} / \mathrm{m}
\end{aligned}
$$

As for the lead rubber bearing

$$
\begin{aligned}
& \mathrm{K}_{\mathrm{D}(\min )}=1499,17 \mathrm{kN} / \mathrm{m} \\
& \mathrm{K}_{\mathrm{M}(\text { min })}=1348,09 \mathrm{kN} / \mathrm{m}
\end{aligned}
$$

stiffness values are allowed to assume an error of $10 \%$, so the stiffness value becomes

$$
\begin{aligned}
\mathrm{K}_{\mathrm{D}(\max )} & =1,10.1499,17=1649,08 \mathrm{kN} / \mathrm{m} \\
\mathrm{K}_{\mathrm{M}(\max )} & =1,10.1348,09=1482,90 \mathrm{kN} / \mathrm{m}
\end{aligned}
$$

3. Response acceleration parameter

From Indonesia seismic zone map, the value of $\mathrm{S}_{1}$ and $\mathrm{S}_{\mathrm{s}}$ at Jakarta are 
868 Safety and Security Engineering V

$$
\begin{aligned}
& \mathrm{S}_{1}=0,69 \\
& \mathrm{~S}_{\mathrm{s}}=0,29
\end{aligned}
$$

So, the values of $S_{\mathrm{D} 1}$ and $\mathrm{S}_{\mathrm{M} 1}$ are as follows

4. Estimate the design displacement

$$
\begin{aligned}
& S_{D 1}=0,352 \\
& S_{M 1}=0,528
\end{aligned}
$$

The design displacement dan maximum displacement for high damping rubber bearing can be estimated with the following formula

$$
\begin{aligned}
& \mathrm{D}_{\mathrm{D}}=\frac{\mathrm{gS}_{\mathrm{D} 1} \mathrm{~T}_{\mathrm{D}}}{4 \pi^{2} \mathrm{~B}_{\mathrm{D}}}=\frac{9,81 \cdot 0,352 \cdot 4,4}{4 \cdot \pi^{2} \cdot 1,65}=0,238 \mathrm{~m} \\
& \mathrm{D}_{\mathrm{M}}=\frac{g \mathrm{~S}_{\mathrm{M} 1} \mathrm{~T}_{\mathrm{M}}}{4 \pi^{2} \mathrm{~B}_{\mathrm{M}}}=\frac{9,81 \cdot 0,528 \cdot 4,6}{4 \cdot \pi^{2} \cdot 1,65}=0,366 \mathrm{~m}
\end{aligned}
$$

As for lead rubber bearing

5. Estimate the total displacement

$$
\begin{aligned}
& D_{D}=0,265 m \\
& D_{M}=0,419 m
\end{aligned}
$$

The total design displacement, $\mathrm{D}_{\mathrm{TD}}$, and total maximum displacement, $\mathrm{D}_{\mathrm{TM}}$, for high damping rubber bearing cannot be taken lesser than this following formula:

As for lead rubber bearing

$$
\begin{gathered}
\mathrm{D}_{\mathrm{TD}}=\mathrm{D}_{\mathrm{D}}\left(1+\mathrm{y} \frac{12 \mathrm{e}}{\mathrm{b}^{2}+\mathrm{d}^{2}}\right) \\
\mathrm{D}_{\mathrm{TD}}=0,238\left(1+\left(\frac{24}{2}\right) \cdot \frac{12 \cdot 0,05 * 24}{24^{2}+24^{2}}\right)=0,274 \mathrm{~m} \\
\mathrm{D}_{\mathrm{TM}}=\mathrm{D}_{\mathrm{M}}\left(1+\mathrm{y} \frac{12 \mathrm{e}}{\mathrm{b}^{2}+\mathrm{d}^{2}}\right) \\
\mathrm{D}_{\mathrm{TM}}=0,366\left(1+\left(\frac{24}{2}\right) \cdot \frac{12 \cdot 0,05 * 24}{24^{2}+24^{2}}\right)=0,421 \mathrm{~m}
\end{gathered}
$$

6. Calculate the base shear

$$
\begin{aligned}
& \mathrm{D}_{\mathrm{TD}}=0,305 \mathrm{~m} \\
& \mathrm{D}_{\mathrm{TM}}=0,482 \mathrm{~m}
\end{aligned}
$$

Base shear based on SNI 1726-2012 can be devided into 2 types, the base shear for designing isolation system and below the isolation system $V_{B}$, and base shear for designing the upper structure $V_{s}$. The calculation of $V_{B}$ and $V_{s}$ for high damping rubber bearing are on the following

$$
\begin{gathered}
\mathrm{V}_{\mathrm{B}}=\mathrm{k}_{\mathrm{DMAX}} \cdot \mathrm{D}_{\mathrm{D}}=2576,69 \cdot 0,238=588,132 \mathrm{kN} \\
\mathrm{V}_{\mathrm{B}}=16 \cdot 588,132=9623,98 \mathrm{kN} \\
\mathrm{V}_{\mathrm{s}}=\frac{\mathrm{k}_{\mathrm{DMAX}} \cdot \mathrm{D}_{\mathrm{D}}}{\mathrm{R}}=\frac{9623,98}{2}=4811,99 \mathrm{kN}
\end{gathered}
$$

As for the lead rubber bearing

$$
\begin{gathered}
\mathrm{V}_{\mathrm{B}}=\mathrm{k}_{\mathrm{DMAX}} \cdot \mathrm{D}_{\mathrm{D}}=1649,08,0,265=436,96 \mathrm{kN} \\
\mathrm{V}_{\mathrm{B}}=16.436,96=6991,3 \mathrm{kN} \\
\mathrm{V}_{\mathrm{s}}=\frac{\mathrm{k}_{\mathrm{DMAX}} \cdot \mathrm{D}_{\mathrm{D}}}{\mathrm{R}}=\frac{6991,3}{2}=3495,66 \mathrm{kN}
\end{gathered}
$$

Based on SNI 1726-2012 base shear for the upper structure $\mathrm{V}_{\mathrm{s}}$ must be taken at least fixed base structure's base shear. From the calculation, the value of 
fixed base structure's base shear is $\mathbf{6 5 2 7 , 3} \mathbf{~ k N}$. So, the upper structure didn't need to be rechecked.

\subsection{High damping rubber bearing preliminary design}

The design procedures of high damping rubber bearing are shown in the following flow chart.

\section{Determine the Design Parameter $\left(\mathrm{k}_{\mathrm{H}}, \mathrm{T}, \beta\right.$, and $\mathrm{D})$}

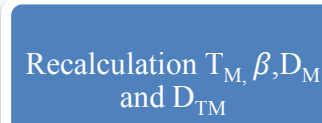

Determine the

Isolator Dimension

(Rubber Diameter

and Thickness)

Figure 3: High damping rubber bearing design flowchart.

And the design summary is shown in Table 1.

Table 1: $\quad$ High damping rubber bearing design table summary.

\begin{tabular}{|c|c|c|c|}
\hline \multicolumn{4}{|c|}{ High Damping Rubber Bearing } \\
\hline Diameter & $=$ & \multicolumn{2}{|c|}{$1100 \mathrm{~mm}$} \\
\hline Rubber thickness & $=$ & \multicolumn{2}{|c|}{$250 \mathrm{~mm}$} \\
\hline G(Shear Modulus) & $=$ & \multicolumn{2}{|c|}{$0.624 \mathrm{MPa}$} \\
\hline \multicolumn{4}{|c|}{ Design Basis Earthquake Parameter } \\
\hline Keff & $=$ & 2359.10 & $\mathrm{kN} / \mathrm{m}$ \\
\hline Qy & $=$ & 217.05 & $\mathrm{kN}$ \\
\hline $\mathrm{Kd}$ & $=$ & 1469.74 & $\mathrm{kN} / \mathrm{m}$ \\
\hline $\mathrm{Ku}$ & $=$ & 14697.42 & $\mathrm{kN} / \mathrm{m}$ \\
\hline Dy & $=$ & 0.02 & $\mathrm{~m}$ \\
\hline Qu & $=$ & 575.74 & $\mathrm{kN}$ \\
\hline$\beta$ & $=$ & $24.89 \%$ & \\
\hline \multicolumn{4}{|c|}{ Maximum Credible Earthquake Parameter } \\
\hline Keff & $=$ & 1892.89 & $\mathrm{kN} / \mathrm{m}$ \\
\hline Qy & $=$ & 297.74 & $\mathrm{kN}$ \\
\hline $\mathrm{Kd}$ & $=$ & 1222.04 & $\mathrm{kN} / \mathrm{m}$ \\
\hline $\mathrm{Ku}$ & $=$ & 12220.37 & $\mathrm{kN} / \mathrm{m}$ \\
\hline Dy & $=$ & 0.02 & $\mathrm{~m}$ \\
\hline $\mathrm{Qu}$ & $=$ & 756.09 & $\mathrm{kN}$ \\
\hline$\beta$ & $=$ & $21 \%$ & \\
\hline
\end{tabular}




\subsection{Lead rubber bearing preliminary design}

The design procedures of high damping rubber bearing are shown in the following flow chart

Determine the Design

Parameter $\left(\mathrm{k}_{\mathrm{H}}, \mathrm{T}, \beta\right.$, and

D)
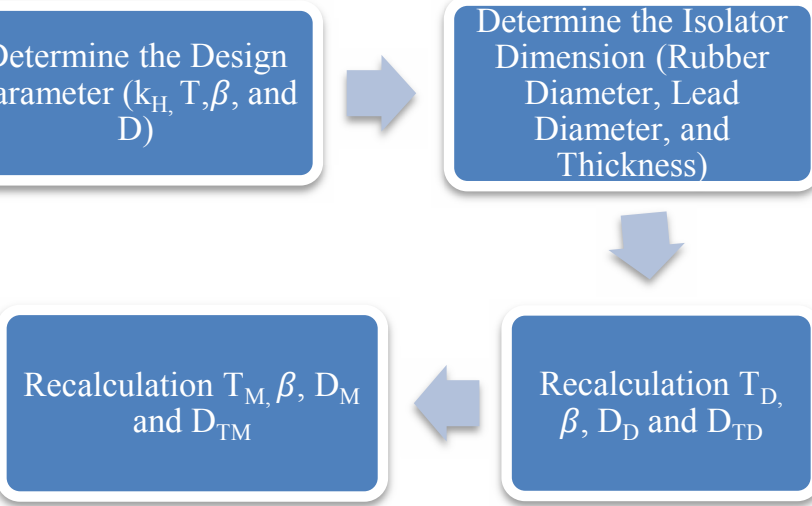

Figure 4: Lead rubber bearing design flowchart.

And the design summary is shown in Table 2.

Table 2: $\quad$ Lead rubber bearing design table summary.

\begin{tabular}{|llcl|}
\hline \multicolumn{4}{|c|}{ Lead Rubber Bearing } \\
\hline Total Diameter & $=$ & $1260 \mathrm{~mm}$ \\
Lead Diameter & $=$ & $180 \mathrm{~mm}$ \\
Rubber thickness & $=$ & $760 \mathrm{~mm}$ \\
Yield Lead & $=$ & $10 \mathrm{MPa}$ \\
G(Shear Modulus) & $=$ & $0.4 \mathrm{MPa}$ \\
\hline \multicolumn{4}{|c|}{ Design Bas is Earthquake Parameter } \\
\hline Keff & $=$ & 1603.13 & $\mathrm{kN} / \mathrm{m}$ \\
Qy & $=$ & 282.74 & $\mathrm{kN}$ \\
Kd & $=$ & 642.87 & $\mathrm{kN} / \mathrm{m}$ \\
Ku & $=$ & 6428.69 & $\mathrm{kN} / \mathrm{m}$ \\
Dy & $=$ & 0.04 & $\mathrm{~m}$ \\
Qu & $=$ & 424.83 & $\mathrm{kN}$ \\
$\beta$ & $=$ & $30 \%$ & \\
\hline & Maximum Credible Earthquake Parameter \\
\hline Keff & $=$ & 1250.00 & $\mathrm{kN} / \mathrm{m}$ \\
Qy & $=$ & 282.74 & $\mathrm{kN}$ \\
Kd & $=$ & 254.47 & $\mathrm{kN} / \mathrm{m}$ \\
Ku & $=$ & 642.87 & $\mathrm{kN} / \mathrm{m}$ \\
Dy & $=$ & 6428.69 & $\mathrm{kN} / \mathrm{m}$ \\
Qu & $=$ & 0.04 & $\mathrm{kN}$ \\
$\beta$ & $=$ & $20.12 \%$ & \\
\hline
\end{tabular}




\section{Analysis}

\subsection{Fundamental periods and modal mass participation factors}

From Table 2 it can be understood that a structure with fixed base system has 1.94 seconds period, a structure with high damping rubber system bearing has 4.24 seconds period, a structure with lead rubber bearing has 4.95 seconds period, meanwhile a structure with combination system has 4.73 seconds period. This is the implication of isolating the structure base which providing a lower stiffness to the nether part of the structure. Consequently, the structure period will shift longer.

Modal mass participation factor for structure with fixed base has reached the value of $91 \%$ on mode 7 and mode 8 , whereas structure with high damping rubber bearing system reached the value of $96 \%$ on mode 2 . Structure with lead rubber bearing system and structure with combination system reached the value of $97 \%$ on mode 2 . Base isolated structure will be varying in shapes which are dominant on mode 1 and mode 2 of the building.

Table 3: $\quad$ Fundamental period and MMPF.

\begin{tabular}{|c|c|c|c|c|c|c|c|c|c|c|c|c|c|c|c|c|}
\hline \multirow{3}{*}{ Mode } & \multicolumn{16}{|c|}{ Modal Mass Participation Factor } \\
\hline & \multicolumn{4}{|c|}{ Fired Base Structure } & \multicolumn{4}{|c|}{ High Damping Rubber Bearing Structure } & \multicolumn{4}{|c|}{ Lead Rubber Bearing Structure } & \multicolumn{4}{|c|}{ Combination } \\
\hline & Period & Ux & Uy & $\mathrm{U}_{2}$ & Period & $\mathrm{Ux}$ & $\mathrm{Uy}$ & $\mathrm{U}_{2}$ & Period & $U_{x}$ & Uy & $\mathrm{U}_{\mathrm{z}}$ & Period & 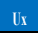 & $\mathrm{Uy}_{\mathrm{y}}$ & $\mathrm{Uz}$ \\
\hline 1 & 1.94 & $1 \%$ & $64 \%$ & $0 \%$ & 4.24 & $82 \%$ & $14 \%$ & $0 \%$ & 4.95 & $96 \%$ & $0 \%$ & $0 \%$ & 4.73 & $97 \%$ & $0 \%$ & $0 \%$ \\
\hline 2 & 1.94 & $65 \%$ & $65 \%$ & $0 \%$ & 4.24 & $96 \%$ & $96 \%$ & $0 \%$ & 4.95 & $97 \%$ & $97 \%$ & $0 \%$ & 4.73 & $97 \%$ & $97 \%$ & $0 \%$ \\
\hline 3 & 1.34 & $65 \%$ & $65 \%$ & $0 \%$ & 3.65 & $96 \%$ & $96 \%$ & $0 \%$ & 4.32 & $97 \%$ & $97 \%$ & $0 \%$ & 4.28 & $97 \%$ & $97 \%$ & $0 \%$ \\
\hline 4 & 0.45 & $76 \%$ & $73 \%$ & $0 \%$ & 1.19 & $96 \%$ & $98 \%$ & $0 \%$ & 1.22 & $97 \%$ & $98 \%$ & $0 \%$ & 1.21 & $97 \%$ & $98 \%$ & $0 \%$ \\
\hline 5 & 0.45 & $84 \%$ & $84 \%$ & $0 \%$ & 1.19 & $98 \%$ & $98 \%$ & $0 \%$ & 1.22 & $98 \%$ & $98 \%$ & $0 \%$ & 1.21 & $98 \%$ & $98 \%$ & $0 \%$ \\
\hline 6 & 0.31 & $84 \%$ & $84 \%$ & $0 \%$ & 0.86 & $98 \%$ & $98 \%$ & $0 \%$ & 0.88 & $98 \%$ & $98 \%$ & $0 \%$ & 0.88 & $98 \%$ & $98 \%$ & $0 \%$ \\
\hline 7 & 0.20 & $91 \%$ & $84 \%$ & $0 \%$ & 0.35 & $98 \%$ & $98 \%$ & $0 \%$ & 0.35 & $98 \%$ & $98 \%$ & $0 \%$ & 0.35 & $98 \%$ & $98 \%$ & $0 \%$ \\
\hline
\end{tabular}

\subsection{Result of non linear time history analysis}

Analyzing the graphical model above, the structure without isolated base will attain its plasticity, whilst the base isolated structure won't. According to that premise, giving base isolator will prevent failure on structural element and will protect the architectural element of the building.
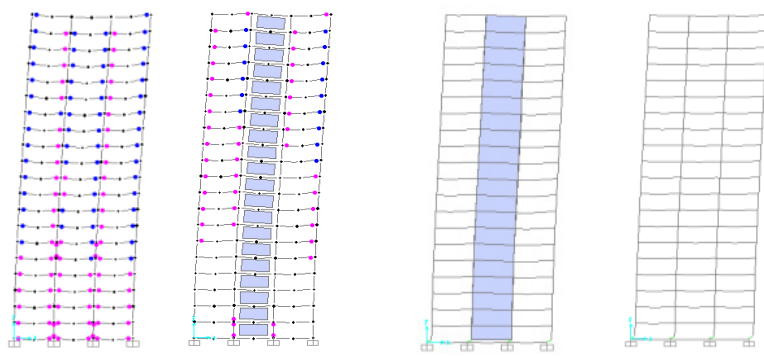

Figure 5: Result of non linear time history analysis. 


\subsection{Base shear}

Analyzing Table 3 below, a structure with a fixed base system will respond more of base shear than base isolated system. It's because that period shift in base isolated system will reduce earthquake acceleration that is channeled to the structure. Thus, there will be less structural base shear in structure.

Different base isolation structural system will create different base shear respond because of the different stiffness and damping-value on each isolator both in high damping rubber system and lead rubber bearing system. Structure with lead rubber bearing system has a smallest base shear respond and structure with high damping rubber bearing system has greater base shear respond.

Also analyzing Table above maximum base shear caused by earthquake will decrease to value $71.8 \%$ in designed earthquake condition (DBE) and to value $63.5 \%$ in maximum earthquake condition (MCE).

Table 4: $\quad$ Base shear maximum response.

\begin{tabular}{|c|c|c|c|c|c|c|}
\hline \multicolumn{7}{|c|}{ Base Shear Maximum Response (kN) } \\
\hline \multirow{2}{*}{ Fixed Base } & \multicolumn{2}{|c|}{ HDRB } & \multicolumn{2}{c|}{ LRB } & \multicolumn{2}{c|}{ Combination } \\
\cline { 2 - 7 } & DBE & MCE & DBE & MCE & DBE & MCE \\
\hline 32230.23 & 9087.628 & 11776.03 & 7441.09 & 8946.392 & 7955.874 & 9713.403 \\
\hline
\end{tabular}

\subsection{Hysteretic curve}

Structure with base isolated system will have a damping ratio $(\xi)$ decrement when maximum earthquake condition occurs. This causes the decrement of ratio between hysteretic energy and static energy. Static energy is increased as the structure deforms, so the damping ratio is getting smaller. Furthermore, according to equipment tests and references of earthquake occurrence, damping ratio of that equipment is slighter because of their own defectiveness.

Structure with high damping rubber bearing system has a damping value that verges to design assumptions. It expresses that structure with high damping rubber bearing is designed effectively.

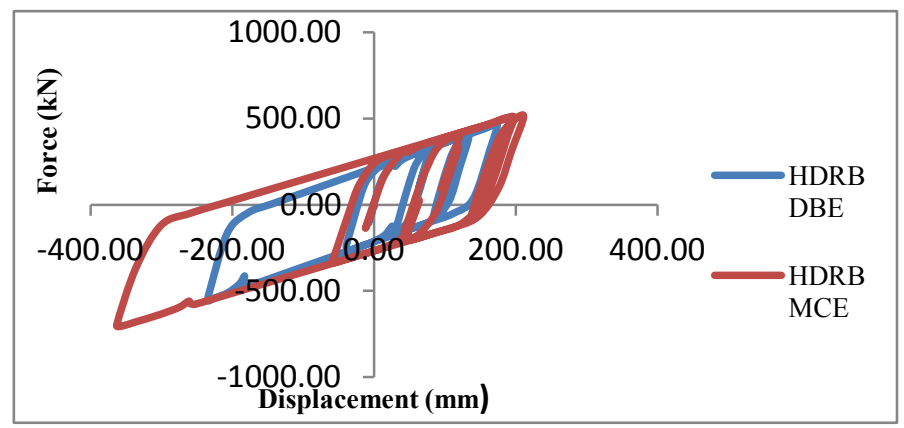

Figure 6: Hysteretic curve of HDRB system. 
Table 5: Damping ratio of HDRB system.

\begin{tabular}{|c|c|c|c|c|c|}
\hline \multicolumn{2}{|c|}{$\begin{array}{c}\text { Damping Ratio at Design Basis Earthquake } \\
\text { Level }\end{array}$} & \multicolumn{3}{c|}{$\begin{array}{c}\text { Damping Ratio at Maximum Considered } \\
\text { Eartquake Level }\end{array}$} \\
\hline Es & 65.34 & kJ & Es & 127.78 & kJ \\
\hline Hysteretic Energy & 186.79 & kJ & Hysteretic Energy & 324.44 & $\mathrm{~kJ}$ \\
\hline$\xi$ & 22.75 & $\%$ & $\xi$ & 20.21 & $\%$ \\
\hline
\end{tabular}

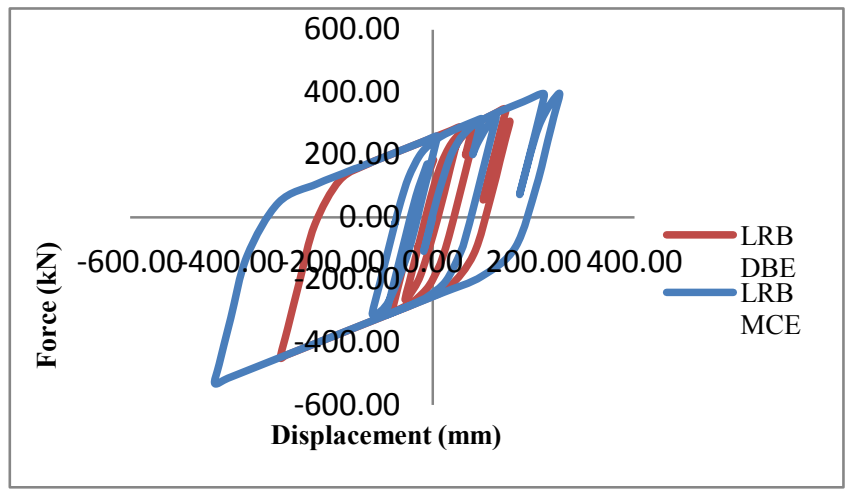

Figure 7: Hysteretic curve of LRB system.

Table 6: Damping ratio of LRB system.

\begin{tabular}{|c|c|c|c|c|c|}
\hline \multicolumn{3}{|c|}{$\begin{array}{c}\text { Damping Ratio at Design Basis Earthquake } \\
\text { Level }\end{array}$} & \multicolumn{3}{c|}{$\begin{array}{c}\text { Damping Ratio at Maximum Considered } \\
\text { Eartquake Level }\end{array}$} \\
\hline Es & 67.71 & kJ & Es & 114.88 & kJ \\
\hline Hysteretic Energy & 186.40 & kJ & Hysteretic Energy & 323.21 & kJ \\
\hline$\xi$ & 21.91 & $\%$ & $\xi$ & 22.39 & $\%$ \\
\hline
\end{tabular}

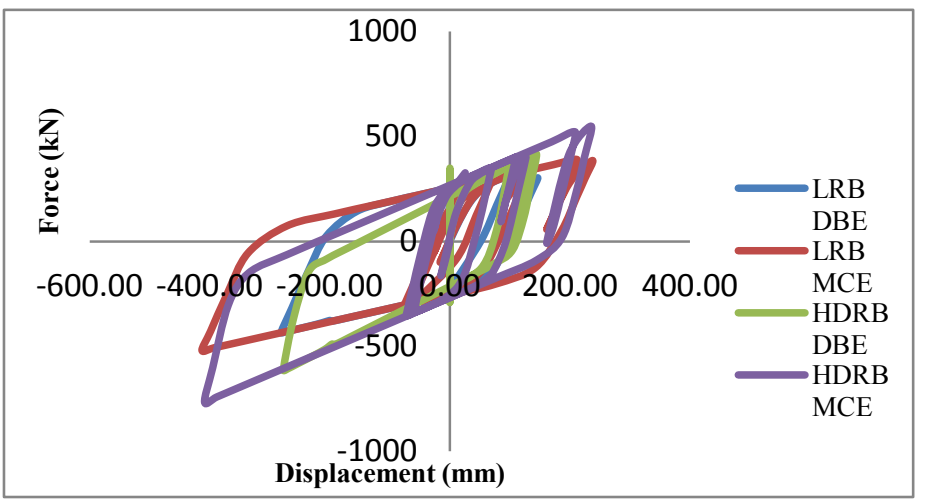

Figure 8: Hysteretic curve of combined system. 
Table 7: Hysteretic curve of combined system.

\begin{tabular}{|c|c|c|c|c|c||c|c|c|c|c|c|}
\hline \multicolumn{4}{|c||}{ High Damping Rubber Bearing } & \multicolumn{6}{c|}{ Lead Rubber Bearing } \\
\hline $\begin{array}{c}\text { Damping Ratio at Design Basis } \\
\text { Earthquake Level }\end{array}$ & \multicolumn{2}{|c|}{$\begin{array}{c}\text { Damping Ratio at Maximum } \\
\text { Considered Eartquake Level }\end{array}$} & \multicolumn{3}{|c|}{$\begin{array}{c}\text { Damping Ratio at Design Basis } \\
\text { Earthquake Level }\end{array}$} & \multicolumn{2}{|c|}{$\begin{array}{c}\text { Damping Ratio at Maximum } \\
\text { Considered Eartquake Level }\end{array}$} \\
\hline Es & 85.05 & kJ & Es & 156.55 & kJ & Es & 60.79 & kJ & Es & 107.37 & kJ \\
\hline $\begin{array}{c}\text { Hysteretic } \\
\text { Energy }\end{array}$ & 249.12 & kJ & $\begin{array}{c}\text { Hysteretic } \\
\text { Energy }\end{array}$ & 401.06 & $\mathrm{~kJ}$ & $\begin{array}{c}\text { Hysteretic } \\
\text { Energy }\end{array}$ & 174.73 & $\mathrm{~kJ}$ & $\begin{array}{c}\text { Hysteretic } \\
\text { Energy }\end{array}$ & 273.04 & $\mathrm{~kJ}$ \\
\hline$\xi$ & 23.31 & $\%$ & $\xi$ & 20.39 & $\%$ & $\xi$ & 22.87 & $\%$ & $\xi$ & 20.24 & $\%$ \\
\hline
\end{tabular}

\section{Conclusion}

From those analyses before, come a few inferences such as:

1. Structure fundamental period on case study 20 levels building with fixed base system is shorter than structure with base isolation system.

2. Structure's Base Shear value on case study 20 levels building with fixed base system and without base isolation system has a base shear value greater than the structure with base isolation system. It's clearly that the shifting period effect can cause the base shear response. The longer the periods of base isolated structure the smaller the value of its base shear.

3. Fundamental period respond, displacement, and structure's base shear with different base isolation system produces a difference in base isolation system's stiffness value of model condition which also is varying.

4. Based on hysteretic curve, structure with high damping rubber bearing and base isolation system can absorb the earthquake energy most effectively.

\section{References}

[1] SNI 1726-2012. Standar Perencanaan Ketahanan Gempa untuk Struktur Gedung dan non Gedung. Indonesian Standard Code.

[2] SNI 03-2847-2002. Tata Cara Perhitungan Struktur Beton Untuk Bangunan Gedung. Indonesian Standard Code.

[3] Anil K. Chopra (1995). Dynamics of Structures: Theory and Applications to Earthquake Engineering. Prentice Hall, Inc., New Jersey.

[4] F. Naeim and J. M. Kelly. (1999). Design of Seismic Isolated Structures. John Wiley \& Sons, Canada.

[5] Farzad Naeim and Ronald L. Mayes. (2009). Design of Structures with Seismic Isolation.

[6] Charles A. Kircher, (2003), NEHRP Recommended Provisions Design Examples: Seismically Isolated Structures, National Institute of Building Sciences, Washington D.C. 